\title{
Critical Thinking and Open-Mindedness in Polarized Times $^{1}$
}

\author{
Susan Verducci \\ San José State University
}

\begin{abstract}
In Teaching Controversial Issues, Nel Noddings and co-author Laurie Brooks invite teachers to engage students in critical thinking on issues that divide Americans such as religion, race, gender, class, and justice. Across her recent work, Noddings argues that schools are places where students can learn to listen to others and to think about these issues critically and collaboratively. This essay proposes that the power of critical thinking for cultivating students' ability to participate in social and political life is complicated by current American polarization and needs to be supplemented by exercises that help open teachers' and students' minds to alternative perspectives. It points to two potential arts education practices that can help create conditions in which critical thinking on controversial issues carries the possibility of cultivating the democratic citizens Noddings envisions, even in polarized times.
\end{abstract}

Keywords: Nel Noddings, critical thinking, arts education, open-mindedness, controversial issues in education, polarization

ISSN 2560-8371

DOI: 10.24908/encounters.v20i1.13446

C) Encounters in Theory and History of Education $\mid 6$ 


\section{La pensée critique et l'ouverture en temps polarisés}

\section{Résumé}

Dans Teaching Controversial Issues, Nel Noddings et co-auteur Laurie Brooks invitent les enseignants à engager les élèves dans une réflexion critique sur les questions qui divisent les américains, telles que religion, race, sexe, classe et justice. Dans l'ensemble de ses travaux récents, Noddings fait valoir que les écoles sont des lieux où les élèves peuvent apprendre à écouter les autres et à réfléchir à ces questions de façon critique et en collaboration. Cet essai soutient que le pouvoir qu'a la pensée critique de cultiver la capacité des étudiants à participer à la vie sociale et politique est compliqué par la polarisation américaine actuelle, et doit être complétée par des exercices qui aident à ouvrir l'esprit des enseignants et des étudiants à d'autres perspectives. II indique deux pratiques potentielles en matière d'éducation artistique qui peuvent aider à créer les conditions dans lesquelles une réflexion critique sur les questions controversées exerce la possibilité de cultiver les citoyens démocratiques que Noddings envisage, même en temps de polarisation.

Mots-clés: Nel Noddings, la pensée critique, l'éducation artistique, l'ouverture d'esprit, les questions controversées en éducation, la polarisation

\section{Pensamiento crítico y mentalidad abierta en tiempos polarizados}

\section{Resumen}

En Teaching Controversial Issues, Nel Noddings y la coautora Laurie Brooks invitan a los maestros a involucrar a los estudiantes en el pensamiento crítico sobre temas que dividen a los estadounidenses, como la religión, la raza, el género, la clase y la justicia. En su reciente trabajo, Noddings argumenta que las escuelas son lugares donde los estudiantes pueden aprender a escuchar a los demás y a pensar sobre estos temas de manera crítica y colaborativa. Este ensayo propone que el poder del pensamiento crítico para cultivar la capacidad de los estudiantes de participar en la vida social y política se complica por la polarización estadounidense actual y debe complementarse con ejercicios que ayuden a abrir las mentes de los maestros y estudiantes a perspectivas alternativas. Se proponen dos prácticas potenciales de educación artística que pueden ayudar a crear condiciones para el pensamiento crítico sobre temas controvertidos y que conlleva la posibilidad de cultivar las visiones de Noddings de ciudadanos democráticos, incluso en tiempos polarizados. 
Palabras clave: Nel Noddings, pensamiento crítico, educación artística, mente abierta, cuestiones controvertidas en educación, polarización

\section{Introduction}

In "Alternative Truths and Untruths: Addressing Polarization in America," Nel Noddings describes polarization as resulting from the economic stagnancy of the bottom $90 \%$ of Americans combined with the explosive growth in sources of information effectively moving people to obtain information from sources aligned with their political perspective. ${ }^{1}$ She cites J.D. Vance, author of the memoir Hillbilly Elegy: "However you want to define these two groups... - rich and poor; educated and uneducated; upperclass and working class - their members increasingly occupy two separate worlds." 2 These worlds are separated by how and where these groups live, their educational background, and what they worry about day to day. Their relationship to each other is increasingly defined by opposition to the other group's ideas, beliefs, policies, understandings, and values.

The force of this opposition can be seen clearly in the world of American politics. In 2014, polling done by the non-partisan Pew Research Center found that,

[t]he overall share of Americans who express consistently conservative or consistently liberal opinions has doubled over the past two decades from $10 \%$ to $21 \%$. And ideological thinking is now much more closely aligned with partisanship than in the past. As a result, ideological overlap between the two parties has diminished: Today, $92 \%$ of Republicans are to the right of the median Democrat, and $94 \%$ of Democrats are to the left of the median Republican. ${ }^{3}$

Americans are increasingly moving away from centrist political ideas, policies, and practices. Congressional redistricting, obstructing executive and judicial appointees, and confrontational and uncivil engagement all contribute to movement away from each other. ${ }^{4}$

In this polarized context, Noddings and co-author Laurie Brooks invite teachers to engage students in connection and dialogue on issues that divide Americans. Their book, Teaching Controversial Issues, suggests that educators and students pursue questions on topics such as religion, race, gender, class, equality, justice, freedom, capitalism, socialism, and so on. ${ }^{5}$ The idea is that teachers help "promote critical thinking in their students" on these specific topics. The authors argue that schools are places where students can learn to listen to others and to think about these issues critically and collaboratively. The work on critical thinking in Teaching Controversial Issues echoes and expands Noddings' work in Educating for Democracy. ${ }^{6}$ As institutions dedicated to the formation of young people, schools are spaces where students can engage critical thinking on controversial issues and, in doing so, 
potentially learn "to find a nucleus of agreement that will provide a starting point from which [they] can work together."7

Promoting critical thinking on the issues that divide Americans generally seems a good idea for cultivating democratic citizens. Why wouldn't we try to think collaboratively and critically in classrooms about the sorts of issues that ultimately affect students' ability to participate in social and political life? Doing so, however, might not have the intended effect. The Pew Center on Research found that "A majority of Americans (63\%) say that when they talk about politics with people they disagree with, they usually find they have 'less in common' politically than they thought previously. Fewer than a third of Americans (31\%) say they find they have more in common with people they disagree with politically." ${ }^{8}$ This poll was made clear to me in a recent lunchtime conversation with four high school girls. During the final day of a blisteringly hot soccer tournament in Las Vegas, the girls had just finished the last of five games and were relaxed, tired, and chatty as we sat at a table scattered with empty plates and drained glasses of lemonade. The conversation turned to a recent discussion the two high school seniors at the table had experienced in a history class. They told the story of a male student with strong and traditionally conservative views on gun control and abortion. Both girls at the table identified with the political left, and both expressed vivid contempt for his views. One of the girls was particularly outraged and gesticulated wildly as she described how the boy demanded the freedom to make his own decision about whether to own a gun. She then stood up and pointed to the other girl and in a triumphant voice claimed the girl had "totally slammed" his position. "Tell them what you said. Tell them!" she prodded, bouncing on her toes. The other girl replied, "I just said that if he had the right to choose to have a gun, that I had the right to choose to have an abortion." The girls high-fived, as though they had won arguments on both gun control and abortion. Neither realized that the "slam" on this boy's position actually forged an ideological connection related to liberty between the adversaries. Whatever direction the conversation in the classroom led to, clearly it did not effectively motivate these two girls to understand the boy's perspective, to inquire deeply about their own position, or to consider the connections between the two. These girls were not open to exploring or questioning ideas on either gun control or abortion; they were only interested in expressing their positions and vanquishing their opponent. This classroom conversation did not "provide a starting point" for working together or lead to the sort of critical thinking Noddings and Brooks propose.

This essay asks whether critical thinking on controversial issues, as Noddings conceives it, provides opportunities for students to work together in polarized times. It proposes that the constructive powers of critical thinking that Noddings suggests need to be supplemented by exercises that help open teachers' and students' minds, and points to two potential arts education practices that might be of help: Visual Thinking Strategies (VTS) and improvisation. Toward this end, I lay out the conception of critical thinking Noddings (and Brooks) suggest for classrooms, a conception which includes 
open-minded listening. Two conceptions of open-mindedness useful for thinking about critical conversations are shared, followed by the delineation of a way the human mind works to shut down serious consideration of alternative perspectives. I then turn to arts education practices that can assist in creating the conditions and habits that can help open minds in conditions of controversy. Finally, I explore the limitations of these practices and of Noddings' hope that critical thinking can help students "find a nucleus of agreement that will provide a starting point from which [they] can work together."

\section{Critical Thinking}

Noddings and Brooks argue that even though critical thinking is typically an educational aim, the conception of "critical thinking" itself is often misguided. Critical thinking is not the "detached, skeptical, and analytical process" often described. ${ }^{10}$ Critical thinkers are neither independent, nor autonomous individuals. They are not objective, impartial beings. Instead, Noddings and Brooks focus on critical thinking as a "dedicated search for meaning and understanding" that requires listening, dialogue, and self-understanding. ${ }^{11}$ This definition of critical thinking considers that the knower cannot be separated from the known. It also requires the employment of logic that cuts through the sort of habitual antagonism that allowed those teenagers to consider themselves adversaries of the young man and bearers of The Truth. Indeed, Noddings' conception is skeptical about aiming for The Truth on controversial issues; instead, it focuses on inquiry, on questioning, on connection, and on aiming for understanding and the creation of meaning.

This conception differs from the persuasive and debate models typically driving classroom discussions.

The object is not necessarily to win a debate. Rather, it is to understand what is being said on all sides and, perhaps, to find a nucleus of agreement that will provide a starting point from which we can work together. The idea is to use critical thinking in contributing to healthy human relations and the maintenance of a strong participatory democracy. Citizens in such a democracy must be able to communicate effectively with one another, and this capacity should be developed in our schools. ${ }^{12}$

To disrupt the forces of polarization around us, Noddings proposes that schools aim to "reduce the communication gap across economic classes," and "to understand what people in opposing classes are going through - not to justify their opinions, but to listen to one another and find ways in which to work together."13 Noddings proposes that an education which includes critical thinking could improve our ability to understand and communicate with others who are different from ourselves, and this ability might "contribute to the creation of a morally connected world."14 


\section{Two Conceptions of Open-Mindedness}

Noddings writes, "Surely, an education for critical thinking must include efforts to produce open-minded listeners who will deliberate on the merits of an argument."15 Here, Noddings implies there is a distinction between listening and open-minded listening. The sort of critical thinking she has in mind requires a mind open to seeing and hearing the other. In this section, I explore two conceptions of open-mindedness relevant for considering Noddings' ideas about open-minded listening and critical thinking on controversial issues in the context of polarization. The first is drawn from education philosopher William Hare, whose work on open-mindedness, beginning in the late 1970s, restarted and reframed a dormant conversation on open-mindedness as an educational aim. Hare describes open-mindedness as "an intellectual virtue that reveals itself in a willingness to form and revise our ideas in the light of a critical review of evidence and argument that strives to meet the elusive ideals of objectivity and impartiality." ${ }^{16}$ He proposes that three "interlocking" and "complementary" components comprise open-mindedness: 1) genuine openness to new ideas; 2) critical assessment of these new ideas; and 3) a willingness and eagerness to revise one's beliefs in the face of evidence. ${ }^{17}$ Hare's conception of open-mindedness assumes the presence of at least two conflicting beliefs, ideas or arguments, and folds critical analysis into its very definition. An open-minded person can set aside her own position and open her mind to a position she does not hold. Critical evaluation ensues. The evidence determines if modifications are to be made to her position, and the entire process is one of rational analysis. Assumed in this conception is the open-minded person's recognition of human fallibility. Open-mindedness, on this account, is the best sort of critical thinking; it aims for truth and understanding and can generate meanings strong enough to potentially change a person's mind.

A more recent conception of open-mindedness, from virtue theorist Jason Baehr, expands thinking on open-mindedness beyond Hare's conflict model and its strictly rational boundaries in a way that resonates with the sort of "open-minded listening" and critical thinking that Noddings has in mind. An "open-minded person is characteristically: (a) willing and (within limits) able (b) to transcend a default cognitive standpoint (c) in order to take up or take seriously the merits of (d) a distinct cognitive standpoint." ${ }^{\prime 8}$ The open-minded person brackets (as much as is humanly possible) her own perspective to discover the inner logic of an alternative position. Her goal is to understand this perspective. The idea of working to transcend one's own standpoint to take up or take seriously that of another's adds important dimensions to Hare's conception. First, it moves open-mindedness beyond the conflict model in that a "distinct cognitive standpoint" doesn't necessarily have to be in conflict with one's own; it just has to be new to the person. For example, one can be open-minded about a paradigm shifting idea, like quantum mechanics. Moreover, open-mindedness can be related to creativity or to solving problems. An artist requires open-mindedness to 
bend, blend, or break aesthetic or material norms, and a detective imagines how details of a crime scene combine to solve a crime. A second dimension introduced in Baehr's conception of open-mindedness is that of standpoint. A person's standpoint, their perspective or view, is formed from their experiences and positions in the physical, social, religious, and political worlds. To understand another's position on a controversial issue requires understanding something about the point and place from which that other person "stands" and "views" the issue. This conception attends to intersectionality and recognizes the significant limitations and difficulty of openmindedness in shifting one's point of view and in understanding the perspective of others.

Hare's model resonates with Noddings' and Brooks' critical thinking on controversial issues in that it requires the thinker to be open to considering positions other than their own, to analyze these positions, and be willing to revise their position when the evidence merits doing so.

Baehr's conception of open-mindedness resonates with the attitudinal and procedural dimensions of Noddings' work on critical thinking - on listening, dialogue and self-understanding. Baehr also draws specific attention to a thinker's situated and limited position, and suggests the need to move beyond one's own standpoint. At the same time, he acknowledges the difficulty of doing so. This open-mindedness recognizes the particularity of persons and our embeddedness in time and place. It also explicitly recognizes the need to try to "take up or take seriously" a distinct cognitive standpoint.

But, what exactly does it mean to "take up or take seriously" a distinct cognitive standpoint? Although Baehr has left little (if any) evidence about what he thinks the differences are, I propose that it is useful to think of taking something seriously as treating an alternative idea or position as something worthy of attention, deserving of respect, and as something external to the examiner. In taking something seriously, the knower and the known are separate. To take something seriously is to acknowledge its value and to apply considerable attention and analysis to it. When I take seriously my daughter's request to spend the weekend alone with her friends in Lake Tahoe, I consider the maturity of her friends, the safety of the accommodations, and the potential dangers they might encounter.

"Taking up," however, has a different connotation. When we "take up" something, we move beyond the consideration of the position as an object outside one's self. When I take up my daughter's Lake Tahoe request, I try to embrace her perspective, to say "yes" to it. I consider her desire for autonomy. I consider that she has grown up there each summer, and knows the lake, the woods, the nearby towns, and the neighbors. I try to see the trip through her eyes. I try to understand the internal logic of her request. I know I can't calibrate her exact perspective, but I can aim for understanding. Here, the knower and the known are not wholly separate. "Taking up" 
means attempting to occupy or adopt the distinct standpoint (as much as is humanly possible); it also requires exploring the inner workings and feel of the position.

Noddings suggests a strategy for reading with students that maps onto the idea of "taking up" the perspective of another. She recommends students "read to believe."

In the study of philosophy, for example, students might be advised to "read and believe" a particular writer for a substantial period of time. This does not mean that everything read should be accepted on authority. Rather, it means that we should establish a reasonable level of understanding before challenging the work at hand. In this approach, believing is used as a strategy. Students are often encouraged to raise challenging questions right from the start, but this move may be a mistake. It may prejudice readers against what follows and close the door to understanding what the writer is trying to accomplish. ${ }^{19}$

"Taking up" a distinct cognitive standpoint requires an effort to understand what another understands or believes, where these beliefs come from, and what the person who advocates for these beliefs is trying to accomplish. The idea is that this is done from occupying the distinct stance of the other person as much as is humanly possible.

I have not chosen the word "occupying" lightly. Myriad limitations and dangers are associated with taking up a distinct cognitive viewpoint. These include: a) the general problem of knowing others' minds; $b$ ) the specific dangers of assuming that one has understood another's point of view; c) the innumerable and intersectional variations that compose a single standpoint; and d) the layers of cognitive and institutional structures that influence one's standpoint. Furthermore, the inquirer's own standpoint filters and directs what is perceived of the other. The limits and dangers of believing that one can accurately takes up another's standpoint is embedded in my use of the word "occupying" with its connotation of invasion.

It is, however, the effort of working toward understanding, of attempting to move into and around the inside of the distinct standpoint that requires opening and that can help one perceive one's own fallibility and one's own position more clearly. Inquiry aimed at understanding and constructing meaning is part of Baehr's openmindedness, as is his nod to the ultimate unknowability of another. Philosopher Michalinos Zembylas captures the problem succinctly: "It seems that there is an inherent paradoxical interaction between knowing and unknowing, learning and ignorance: At the same time that we are eager to explore and learn things (including learning about the Other), we have to admit that things (and the Other) are mysterious and unknowable." ${ }^{20}$ Taking up recognizes itself as an impossible and paradoxical strategy that aims for taking in, as fully as is humanly possible, a position or idea that one does not currently hold. 
What underlies most conceptions of open-mindedness is intellectual humility, a stance toward one's self as a fallible knower, and a stance toward inquiry as riddled with obstacles and impossibilities. Taking up, as part of opening one's mind, is not empathy; it does not aim to experience what the other experiences. It is more aligned with Barbara J. Thayer-Bacon's description of critical thinking as constructive work that includes reasons, emotions, intuition, and imagination, and in which thinkers recognize themselves as "fragile, socially dependent, subjective human beings" and knowers. $^{21}$

The next section explores specific difficulties involved in opening one's mind to perceive another's standpoint, particularly in conditions of strong belief.

\section{The Shutting Out of Alternative Perspectives}

In How We Think, John Dewey writes, "[t]o maintain the state of doubt and to carry on systematic and protracted inquiry - these are the essentials of thinking." 22 And yet, as humans, we are full of convictions, especially when it comes to controversial issues, and especially in polarized times. Although the word "controversy" carries doubt and uncertainty in its nature, controversial issues are often topics where we experience the most felt certainty, the most conviction. Conviction, however, is often antithetical to openness and may unconsciously operate to protect and perpetuate itself. The human mind habitually forecloses the perception, taking up, and taking seriously of alternative perspectives.

\section{Cognitive Dissonance and Motivated Reasoning}

A man with a conviction is a hard man to change. Tell him you disagree and he turns away. Show him facts or figures and he questions your sources. Appeal to logic and he fails to see your point....Suppose that he is presented with evidence, unequivocal and undeniable evidence, that his belief is wrong: what will happen? The individual will frequently emerge, not only unshaken, but even more convinced of the truth of his beliefs than ever before. ${ }^{23}$

These words introduced the theory of cognitive dissonance back in 1956 in When Prophecy Fails. Social psychologists Leon Festinger, Henry Riecken, and Stanley Schacter studied a small religious group called The Seekers. The Seekers prophesized that, on December 21, 1954, a UFO carrying spacemen would arrive to rescue them from a global apocalypse. These spacemen would take them to other planets and train them to lead the recovery back on earth. The researchers infiltrated the group, and studied what happened when the prophecy was disconfirmed. Their observations led 
them to introduce the theory of cognitive dissonance, a theory which continues to inform psychology's understandings of motivation.

In its most simplistic form, cognitive dissonance proposes that when a person holds an understanding (cognition) and then encounters another cognition that is inconsistent with the original, the inconsistency creates a dissonance or discomfort that the person then tries to resolve, reduce or eliminate. Prophecy researchers found that reducing the discomfort takes at least one of three forms: 1) a person alters their belief, attitude, or behavior to create consonance (for example, she no longer believes that spacemen are coming); 2) a person seeks and acquires additional information that makes the new cognition consistent with other cognitions; or 3) a person engages in compensatory behaviors, including ignoring, minimizing, or trivializing the discrepancy ("It was just that the date of the landing was incorrect"), rationalizing ("The UFO had a mechanical failure and is delayed"), and/or avoiding information likely to enhance the inconsistency (only looking to other Seekers for information). The theory is that the psychological discomfort creates pressures to act in ways that reduce the discomfort. The goal is a psychological equilibrium in which there is consistency between beliefs, opinions, attitudes, emotions, and behavior. This consistency is not simply a preference in the theory of cognitive dissonance; it is a human drive and a forceful motivator.

Not surprisingly, human perception, processing, and reasoning are affected by this drive. The first reduction strategy indicates an openness of mind and a willingness to examine the new information and change one's mind if the facts/argument stand(s) up to scrutiny. The dissonance creates doubt and motivation to inquire and learn. The term "motivated reasoning" was coined to describe the latter two strategies: in motivated reasoning, a person's inquiry no longer aims for truth and understanding; instead, it shifts to serve the goal of reducing the discomfort of inconsistent cognitions. This shift creates resistance to perceiving facts, generates the conscious or unconscious ignoring of facts, and/or reduces the force of facts and evidence. Chris Higgins, following Freud, calls the latter "disavowal"; "What is disavowed is not the piece of reality that challenges my belief, but its challenge. The idea is accepted but trivialized or compartmentalized." ${ }^{24}$ Motivated reasoning is not about understanding something or creating meaning. The goal is getting comfortable, getting consistent. In conditions of polarization and when strong beliefs are held closely and tightly, introducing disconfirming information can twist inquiry into a defensive stance.

When people hold beliefs or attitudes in committed ways, they typically have invested time, energy, and often aspects of their identity into these beliefs, opinions, attitudes, and actions. They can be particularly resistant to perceiving and/or understanding alternative perspectives. This resistance can clearly be seen in American politics. Recent research done by Brenden Nyhan and Jason Reifler found that when false or unsubstantiated beliefs in politics are corrected, they "frequently fail to reduce misperceptions among the targeted ideological group." Surprisingly, these 
researchers also found "several instances of a 'backfire effect' in which corrections actually increase misperceptions among the group in question." ${ }^{25}$ Here, when subjects with particularly strong political beliefs were provided with corrective facts, the consequence was an increase in their preexisting false belief. ${ }^{26}$ Research from Cass R. Sunstien et al. also shows that when people received information confirming their preexisting beliefs, those beliefs were strengthened, whereas disconfirming information was simply dismissed. ${ }^{27}$ These two studies show the way polarization can be amplified by new information, as people asymmetrically update their beliefs. Information, facts, discussion, and reasoning - all components of critical thinking - may not be helpful in finding a starting point from which people might work together in these polarized times. In fact, they may themselves be polarizing. The critical thinking on controversial issues that Noddings advocates assumes that minds are open to take up or take seriously alternative perspectives. This research and my conversation with those teenage girls reveal that this assumption is problematic.

Even when minds are open to take up or take seriously an alternative standpoint, doing so must be infused with recognition of the impossibilities of understanding another's perspective, including complex layers of issues of identity and positionality. Furthermore, critical thinking may not have the force to disrupt the myriad biases and workings of the mind that hinder us from perceiving or taking seriously facts and ideas that challenge our convictions. Our reasoning can become motivated to defend convictions, not to seek understanding and meaning. At lunch with the teenagers, my efforts to engage them regarding the connections between the boy's argument on gun control and their position on abortion was met with instant resistance and a sharp glance from my daughter warning me off challenging her friends. Conditions where cognitive dissonance could be productively employed to spark doubt and inquiry were not present. And yet, these conditions are necessary for Noddings' open-minded listening to alternative perspectives.

\section{Opening Minds Through the Arts}

As the previous sections emphasize, to facilitate open mindedness in circumstances of strong and polarized belief requires an "opening" of minds in addition to engaging critical thinking. It is important to avoid (as much as is humanly possible) biases, habits of thinking, and motivated reasoning that can automatically and unconsciously engage during these conversations. In Human Nature and Conduct, John Dewey employs a helpful analogy to describe the problem of habitual thinking and offer insight into ways forward. He describes an alcoholic trying to quit drinking by thinking about quitting drinking. 
The hard-drinker who keeps thinking of not drinking is...starting with the stimulus to his habit [drinking]. To succeed he must find some positive interest or line of action which will inhibit the drinking series [the habits] and which by instituting another course of action will bring him to his desired end. In short, the man's true aim is to discover some course of action, having nothing to do with the habit of drink... which will take him where he wants to go....Until one takes intermediate acts seriously enough to treat them as ends, one wastes one's time in any effort at change of habits. $^{28}$

Teachers and students ought not to start with direct engagement with controversial issues because, when they do, habitual thinking and motivated reasoning engage automatically. Mediating forces are required to help open people to consider others' perspectives as well as their own. One needs to find courses of action that help us think openly and critically on topics of uncertainty before engaging controversy. Jumping right into conversations on race, religion, gun control or abortion, without first creating habits and a culture of openness, will likely be self-defeating.

In what follows, I point to two arts education practices that can help build a classroom culture in which critical thinking in the context of uncertainty can flourish in the way Noddings and Brooks intend. These practices help teachers and students draw forth multiple alternative perspectives and perceive the limits of their own viewpoints and thinking capacities. These practices also allow students and teachers to learn to think comfortably in the context of uncertainty, ambiguity, and ambivalence. They create cognitive dissonance and engage skills of careful looking and listening, tentative interpreting, full sharing, and subsequent reinterpreting. I propose that these exercises can help students develop practices that contribute to opening minds in the context of uncertainty and conviction.

\section{Visual Thinking Strategies}

Visual Thinking Strategies (VTS) is an arts education practice developed by museum educator Phillip Yenawine and cognitive psychologist Abigail Housen ${ }^{29}$ - a practice that can be employed in any classroom. It consists of revealing a single intriguing or ambiguous work of art, followed by moments of silent looking. These moments of silence last long enough that students move beyond an initial impression, but not so long that they lose interest. After looking, the teacher asks, "What's going on here?" A student proposes an interpretation. The teacher then asks, "What do you see that makes you say that?" As the student answers, the teacher points to the details the student highlights as the evidence for her interpretation. The teacher does this to be sure that everyone (herself included) sees what the interpreter sees. She then paraphrases what the student said, asking the interpreter for clarification. The teacher thanks the student and asks the class, "What more can we find?" After each round of 
these questions, the teacher links new interpretations to previous interpretations. The cycle of three questions - What is going on here? What do you see that makes you say that? and What more can we find? - continues in a loop until students finish proposing interpretations. ${ }^{30}$

What is critical in this practice is that the teacher facilitates but does not lead the discussion, and that she never proposes a "correct" interpretation or uses evaluative language in responding to students' interpretations. She never utters "Good point!" or "That seems right." This process does not aim for consensus; engagement in the process of perception and inquiry is the goal. No "answers" are provided; students inquire jointly, but are ultimately left to construct their own understandings and to make the work of art meaningful to themselves.

To employ this strategy effectively for the critical thinking Noddings has in mind, the teacher selects works of art or even everyday materials that can lead to different interpretations. ${ }^{31}$ Instead of inquiring directly together on questions of religion, race, gender, etc., questions that are bound to draw forth students' biases and motivated reasoning, students practice inquiring openly together in a context where no expectation of a single black or white truth exists. The arts are arenas in which uncertainty, ambiguity and ambivalence are accepted and respected. Engagement with others in interpreting art through VTS can build genuine inquiry skills in this context of uncertainty.

VTS sheds light on how critical thinking can work in relation to controversial issues as well. First, it highlights the inherent limitations of individual perception and perspective. It becomes clear through the process that multiple perspectives on the artwork contribute to increasingly better perception, but not necessarily consensus. Second, it draws forth alternative perspectives. Third, it underscores one's fallibility as a knower. Student comments typically show evolution in understanding, despite the lack of a single "correct" interpretation. Fourth, VTS highlights the process of perceiving, of seeing, of interpreting, and reinterpreting, a process that teacher facilitation slows down and underscores. Fifth, it requires that students listen (at least twice) to each student's reasons for the interpretation. Sixth, it suggests there is always more to see and know and asks students to keep looking. Finally, the process builds community, drawing out students who may be hesitant to speak in class, and teaches respectful engagement. VTS helps open students to engage constructively with each other on topics about which they may disagree, but not with ones likely to engage motivated reasoning.

\section{Improvisation}

Collective improvisation can "open" its players by "interrupting the given" and "unfixing" certainties. ${ }^{32}$ In theatrical improvisation, pioneer Keith Johnstone introduced 
the idea of "tilting" in an improvised scene. Players reframe the context of the scene or the status of the players when they "tilt." For example, a scene opens with two people on a honeymoon, and then one spouse introduces a valet who he has hired to perform sex for him. ${ }^{33}$ The foundational assumptions of the scene are disrupted and reorganized. Skilled improvisers never reject the "tilt." As master improviser and The Second City alum Tina Fey tells us,

The first rule of improvisation is AGREE. Always agree and SAY YES. When you're improvising, this means you are required to agree with whatever your partner has created. So if we're improvising and I say, "Freeze, I have a gun," and you say, "That's not a gun. It's your finger. You're pointing your finger at me," our improvised scene has ground to a halt. But if I say, "Freeze, I have a gun!" and you say, "The gun I gave you for Christmas! You bastard!" then we have started a scene because we have agreed that my finger is in fact a Christmas gun. ${ }^{34}$

"Tilting" and "Saying Yes" make improvisation relevant for the opening of minds. In collective improvisation, players create a space filled with destabilizing forces in which equilibrium is achieved, only to be thwarted, again and again. It does not matter if the improvisation takes the form of music, theater, or dance. Here is the key aspect: even though the past is known, the future is always uncertain. In fact, the act of improvising is characterized as "unsettling certainties" by philosopher Panagiotis Kannellopoulos. ${ }^{35}$ Meanings are collectively made and remade through intentional disruptive actions. Habitual responses are blocked and the space is filled with destabilizing forces. Players open themselves and their partners to an unpredictable and contingent future.

Both these arts education exercises are kin to Dewey's "intermediate acts" in that they work to change habits, build comfort living with disruption, create cognitive dissonance that motivates inquiry, and facilitate critical thinking on issues in which there are few clear or correct answers. They resemble the drills that athletes practice to develop discrete skills. Of course, drills do not fully prepare athletes for games. They do, however, build skills that games, and engaging students in conversations on critical issues, depend upon. ${ }^{36}$

\section{Limitations}

What remains to be explained is how Noddings' work and my extension of it remain significantly limited. For example, the conceptions of critical thinking and openmindedness we employ are highly decontextualized and refer primarily to the internal workings of individuals. These narrow conceptions bracket structural forces and inequities that often transform conversations on controversial topics into exercises perpetuating an unequal power status quo. We know that critical thinking and open- 
mindedness are not simply processes and skills that occur within an individual; institutional structures and cultural forces also define what critical thinking looks like, who engages in it, what it means to be open, and what is considered a controversial issue. Moreover, institutions such as schools function to create, perpetuate and maintain social, economic, and political stratification and division.

This essay also assumes students have access to alternative perspectives in their schools. Further, it assumes that students have equity in terms of power and voice. We know that neither of these conditions exist in American education. Schools themselves are segregated by race, by economic class, by language, by culture, by privilege and so on. ${ }^{37}$

Finally, history reveals numerous occasions where divisive issues require divisive action for moral progress (consider the Civil War and World War II). In these cases, the educational aim of working together is, at some point, neither possible nor desirable. Should one "open" to alternative standpoints of pedophiles? Or fascists? Rachel Wahl articulates this problem of open-mindedness succinctly in the context of the political violence that took place in Charlottesville, Virginia during the Neo-Nazi rallies of August 11th and 12th in 2017. "[l]f the problem is systematic oppression, then the tools of disruption and resistance are needed; to open oneself to diverse positions is to equivocate between what should in fact be clear moral lines." ${ }^{38}$ Matt Ferkany also questions whether openness in such circumstances is akin to "sympathy with the devil." ${ }^{\prime 9}$ Both history and these authors provide provocative challenges to an unquestioned valuing of open minds. Some differences and inequities require short term action that further divides us. Conversation, in these contexts, is the last thing we need.

Although these critical considerations cannot be ignored, not every problem is one of systematic oppression. We still need to explore the possibilities involved in opening minds to perceive, to take up or to take seriously alternative perspectives. However, it is important to note that this exploration addresses only one aspect of a highly complex landscape of theoretical and practical pedagogical considerations relevant for cultivating democratic citizens. Much more work must be done.

\section{Conclusion}

The critical thinking on controversial issues in schools that Noddings (and Brooks) propose in Teaching Controversial Issues and Educating for Democracy requires conditions in which students and teachers open to alternative perspectives. In the context of polarization, this sort of openness requires a classroom culture and practices in which habitual thinking is challenged, cognitive dissonance is cultivated, and the reasoning resulting from its discomfort is motivated by the desire for truth, understanding, and the creation of meaning. Students need to practice inquiry in 
contexts of uncertainty, ambiguity, and ambivalence on issues of value, but not (at least not at first) on such highly divisive and polarized issues as race, religion, immigration, and so on. The idea is to make the practices of opening and critical thinking comfortable and routine - to develop new habits and relationships that can support direct conversations on issues that divide us.

I have proposed two arts education practices that might further these aims. We might move from discussion and engagement with art to beliefs and standpoints on controversial issues by creating the sort of relational and moral communities in schools that Noddings has explored fully in her work on caring and peace studies, and which she and Brooks also consider in Teaching Controversial Issues. The arts education practices delineated in this essay can contribute to creating such communities by engaging students and teachers in inquiry, sensitizing them to difference, and allowing them to see, hear and take up another's position in ways that respect others' experiences and standpoints. Even when deep divisions in values, beliefs, and perspectives exist, one hopes that habits of openness, genuine inquiry, and critical thinking that aim for understanding and meaning will prevail. However, before those teens can start working together, they (and the rest of us for that matter) must be able to open themselves to perceive the respect for liberty that they all hold.

\section{Notes}

1. My thanks to my colleague Michael Katz for his help in polishing the language used in this essay.

1. Nel Noddings, "Alternative Truths and Untruths: Addressing Polarization in America," University of South Florida College of Education keynote address, April 28, 2017, accessed February 18, 2019, https://www.usf.edu/education/documents/aboutus/news/2017/education-nel-noddings-research-paper.pdf; see p. 4.

2. J.D. Vance, Hillbilly Elegy (New York: Harper Collins, 2016), 252.

3. Pew Reseach Center, Political Polarization in the American Public, June 12, 2014, accessed June 15, 2019, https://www.people-press.org/2014/06/12/politicalpolarization-in-the-american-public/.

4. Pietro S. Nivola, "Thinking About Political Polarization," The Brookings Institution, January 1, 2005, accessed May 3, 2019, https://www.brookings.edu/research/thinkingabout-political-polarization/; Christopher Hare, Keith T. Poole, and Howard Rosenthal, "Polarization in Congress has Risen Sharply: Where is it Going Next," Washington Post, February 13, 2014, accessed May 3, 2019, https://www.washingtonpost.com/ news/monkey-cage/wp/2014/02/13/polarization-in-congress-has-risen-sharply-whereis-it-going-next/?utm_term=.22f9c84e6e60. 
5. Nel Noddings and Laurie Brooks, Teaching Controversial Issues: The Case for Critical Thinking and Moral Commitment in the Classroom (New York: Teachers College Press, 2017), 4.

6. Noddings and Brooks, Teaching Controversial Issues; Nel Noddings, Education and Democracy in the 21st Century (New York: Teachers College Press, 2013).

7. Noddings and Brooks, Teaching Controversial Issues, 1.

8. Pew Research Center, "More Now Say It's 'Stressful' to Discuss Politics With People They Disagree With," November 5, 2018, accessed May 3, 2019, https://www.peoplepress.org/2018/11/05/more-now-say-its-stressful-to-discuss-politics-with-peoplethey-disagree-with/.

9. Noddings and Brooks, Teaching Controversial Issues, 1.

10. Ibid.

11. Ibid.

12. Ibid.

13. Noddings, "Alternative Truths and Untruths," 4.

14. Ibid.

15. Noddings, Education and Democracy, Kindle location 3189.

16. William Hare, "Helping Open-mindedness to Flourish," Journal of Thought (2011): 9.

17. William Hare, "Education for an Unsettled World: Dewey's Conception of Openmindedness," Journal of Thought 39, no. 3 (2004): 118.

18. Jason Baehr, The Inquiring Mind: On Intellectual Virtues and Virtue Epistemology (Oxford: Oxford University Press, 2011), Kindle location 1939.

19. Noddings and Brooks, Teaching Controversial Issues, 31.

20. Michalinos Zembylas, "A Pedagogy of Unknowing: Witnessing Unknowability in Teaching and Learning," Studies in Philosophy and Education 24 (2005): 140.

21. Barbara J. Thayer-Bacon, Transforming Critical Thinking: Thinking Constructively (New York: Teachers College Press, 2000), 30, 93.

22. John Dewey, How We Think (Lexington, MA: D.C. Heath, 1910), 13.

23. Leon Festinger, Henry W. Riecken, and Stanley Schacter, When Prophecy Fails (London: Printer \& Martin Ltd, 1956/2008), 3.

24. Chris Higgins, "Open-mindedness in Three Dimensions," Paideusis 18, no 1 (2009): 48.

25. Brenden Nyhan and Jason Reifler, "When Corrections Fail: The Persistence of Political Misperceptions," Political Behavior 32, no. 2 (2010): 330.

26. The political topics studied included Iraq's possession of weapons of mass destruction prior to the Iraq war and the fiscal effects of tax cuts.

27. Cass R. Sunstein, Sabstan Babadill-Suarez, Stephanie Lazzaro, and Tali Sharot, "How People Update Beliefs about Climate Change: Good News and Bad News," 
September 2, 2016, accessed July 7, 2019, https://papers.ssrn.com/sol3/papers.cfm? abstract_id=2821919.

28. John Dewey, "Habits and Will," in Human Nature and Conduct: An Introduction to Social Psychology (New York: Modern Library, 1922), 15-42; see p. 35.

29. Philip Yenawine, Visual Thinking Strategies: Using Art to Deepen Learning Across School Disciplines (Cambridge, MA: Harvard Education Press, 2013).

30. An extension of this practice folds in information from the historical time period, the art world and/or artist after the initial round of questions. The cycle of three questions then repeats.

31. One excellent resource can be found in The New York Times learning network's "What's going on with this picture." The Times posts photographs for the use of VTS in schools. See The New York Times, https://www.nytimes.com/column/learning-whatsgoing-on-in-this-picture.

32. Gary Peters, The Philosophy of Improvisation (Chicago: University of Chicago Press, 2009), 3.

33. Keith Johnstone, Impro for Storytellers: Theatresports and the Art of Making Things Happen (London: Faber and Faber, 1999), 356.

34. Tina Fey, Bossypants (New York: Little, Brown and Company, 2011), 83-84.

35. Panagiotis Kanellopoulos, "Freedom and Responsibility: The Aesthetics of Free Musical Improvisation and Its Educational Implications - A View from Bakhtin," Philosophy of Music Education Review 19, no. 2 (2011): 127.

36 . For a more thorough exploration of improvising and opening minds, see Susan Verducci, "Opening Minds Through Improvisation," edited by Eduardo Duarte, Philosophy of Education Yearbook 2015, 497-505.

37. See, for example, Jonathon Kozol, The Shame of the Nation: The Restoration of Apartheid Schooling in America (New York: Three Rivers Press, 2005).

38. Rachel Wahl, Educational Theory (in press, 2019).

39. Mathew Ferkany, Educational Theory (in press, 2019). 